\title{
Perangkat Penghitungan dan Penentuan Kualitas Produksi Telur Ayam Berbasis Mikrokontroler Terintegrasi Smartphone
}

\author{
Helda Yenni ${ }^{1 *}$, Susanti ${ }^{2}$ \\ ${ }^{1,2}$ STMIK Amik Riau \\ Jl. Purwodadi Indah Km.10 Panam Pekanbaru-Riau 28294 \\ "heldayenni@stmik-amik-riau.ac.id
}

\begin{abstract}
Agribusiness nowadays is getting growing. Supported by the rapid growth of technology, encouraging companies to utilize modern technology in improving their productivities. Including the business engaged in the production of chicken eggs. At this time the manual system is still used in the activities of calculating the amount of production and control the selection of the feasibility of selling the production. The manual system takes a long time, human resources and calculation results are not accurate. It can also potentially lead to cheating of employees who are likely to manipulate production for personal gain. The loss of a company is an absolute consequence. One alternative solution to deal with the problem is to build an automated system. In the research that has been done, generated a system that is able to calculate and select the results of production that match the standards of selling and not appropriate. This system is built by combining hardware and software capabilities. The main components used, namely Ultrasonic Sensors that can detect every egg produced, Single Board Computare Raspberry Pi as master module who served as the main controller, light sensor to detect the quality of the feasibility of eggs and the database to record the amount of production. The system also integrates with the website and can be accessed via computer devices as well as other mobile devices. Thus the resulting system can minimize the loss of the company by producing an accurate production count calculation and production selection control produced according to the standard worthy of selling or not. This can make it easier for leaders and stakeholders to monitor mobile products.
\end{abstract}

Keywords : Microcontroller, Chicken Egg Production, website, smartphone

\begin{abstract}
Abstrak
Pertumbuhan bidang agrobisnis semakin berkembang. Didukungdengan pertumbuhan teknologi yang begitu pesat, mendorong perusahaan untuk memanfaatkan teknologi modern dalam meningkatkan produktivitas perusahaan. Termasuk diantaranya usaha yang bergerak dibidang produksi telur ayam.Pada saat ini sistem manual masih digunakandalam kegiatan penghitungan jumlah produksi maupun kontrol seleksi kelayakan jual hasil produksi tersebut. Sistem manual membutuhkan waktu yang lama, sumber daya manusia dan hasil perhitungan yang tidak akurat. Hal ini juga dapat berpotensi terjadinya kecurangan dari karyawan yang berpeluang untuk memanipulasi hasil produksi untuk kepentingan pribadi. Kerugian perusahaan merupakan konsekuensi yang mutlak terjadi. Salah satu solusi alternatif untuk menangani permasalahan tersebut adalah dengan membangun sistem yang terotomatisasi. Pada penelitian yang telah dilakukan,dihasilkan sebuah sistem yang mampu melakukan penghitungan dan menyeleksi hasil produksi yang sesuai standar kelayakan jual dan yang tidak sesuai. Sistem ini dibangun dengan menggabungkan kemampuan hardware dan software. Komponen utama yang digunakan, yakni Sensor Ultrasonik yang dapat mendeteksi setiap butir telur yang dihasilkan,Single Board ComputareRaspberry Pi sebagai module master yang bertugas sebagai pengendali utama, sensor cahaya untuk mendeteksi kualitas kelayakan telur serta databaseuntuk merekam jumlah produksi. Sistem juga terintegrasi dengan website dan dapat diakses melalui perangkat komputer maupun perangkat mobile lainnya. Dengan demikian sistem yang dihasilkan dapat meminimalisirkerugian perusahaan dengan menghasilkan perhitungan jumlah produksi yang akurat dan kontrol seleksi produksi yang dihasilkan sesuai standar layak jual atau tidak. Hal ini dapat mempermudah pimpinan maupun pihak terkait untuk melakukan pemantauan terhadap hasil produksi secara mobile.
\end{abstract}

Kata kunci : Mikrokontroler, Produksi Telur Ayam, website, smartphone 


\section{Pendahuluan}

Usaha peternakan ayam ras petelur merupakan salah satu ternak unggas yang dapat mendukung program pemerintah, karena keunggulannya dalam memproduksi telur. Berkembangnya usaha peternakan ayam ras petelur dapat memberikan sumbangan dalam pemenuhan gizi dengan harga yang terjangkau pada kalangan masyarakat. Usaha ini mampu menyediakan lapangan kerja tidak hanya terbatas di pedesaan tetapi juga di perkotaan [1]. Rantai proses produksi telur akan dapat meningkatkan profit perusahaan.

Untuk menstabilkan dan memantapkan usaha ternak ayam petelur, maka peternak harus melakukan perbaikan di berbagai aspek, yang mencakup aspek produksi, manajemen pengelolaan, biosekuriti dan aspek pemasaran [2]. Dalam konteks market driven, pengembangan komoditas peternakan khususnya telur perlu dipahami perkembangan dua bentuk pasar, yaitu pasar modern dan pasar konvensional serta kebijakan terkait dengan pengembangan rantai pasok produk peternakan [3].Terjadinya peningkatan produksi telur ayam ras petelur sebesar $3,65 \%$ di tahun 2015, dibandingkan dengan tahun sebelumnya. Khusus untuk wilayah Provinsi Riau, jumlah produksi mencapai 1.034 ton[4].

Mikrokontroler adalah suatu chip dengan kepadatan yang sangat tinggi, dimana semua bagian yang diperlukan untuk suatu kontroler sudah dikemas dalam satu keping, biasanya terdiri atas CPU (Central Processing Unit), RAM (Random Access Memory), EEPROM/EPROM/PROM/ROM/, I/O, Timer dan lain sebagainya [5].

Penelitian terkait penerapan mikrokontroler untuk peternakan, telah dibahas oleh beberapa peneliti sebelumnya. Aji Ridhamuttaqin,dkk [6] membuat model sistem pemberi pakan ayam otomatis berbasis fuzzy logic control. Pada penelitian tersebut menggunakan mikrokontroler ATMega8535 dan dan logika fuzzy untuk mengatur waktu dan jumlah pakan ternak.

Penelitian yang dilaksanakan oleh Suriansyah,dkk [7] menghasilkan sistem data logger yang menggunakan MMC sebagai media penyimpanan data hasil perhitungan jumlah telur yang diproduksi. Vinda Wijayanti,dkk [8] melakukan penelitian penyortiran telur berdasarkan kualitas telur secara otomatis dengan menggunakan mikrokontroler PIC16F84. Keunggulan dari perangkat yang dibangun adalah dapat menyeleksi telur baik dan telur busuk (jelek) dengan cepat tanpa menyeleksi satu per satu secara manual.

Berdasarkan penelitian terdahulu tersebut, maka peneliti akan mengembangkannya dalam rangka eksplorasi lanjut atas kemampuan mikrokontroler. Pada penelitian ini penulis membuat sebuah sistem perhitungan jumlah produksi telur ayam secara otomatis dengan menggabungkan kemampuan mikrokontroler ATMega328,sensor ultrasonik dan sensor inframerah dan sensor pendeteksi cahaya. Sistem perhitungan yang dihasilkan menggunakan ATMega328 sebagai pusat utama sistem yang dibangun. Sistem akan melakukan perhitungan otomatis setiap butir telur yang diproduksi melewati jalur yang dirancang sedemikian rupa dan sensor ultrasonik diletakkan pada bagian ujung jalur untuk mendeteksi setiap butir telur yang melewati sensor. Sensor inframerah dan sensor pendeteksi cahaya digunakan sebagai kontrol seleksi dan juga kontrol dalam perhitungan. Pemilik peternakan ataupun pihak terkait dapat memperoleh informasi jumlah produksi dengan menggunakan komputer dan juga dapat mengakses melalui smartphone. Diharapkan dengan adanya sistem ini, dapat dijadikan salah satu solusi untuk peningkatan efisiensi dan efektifitas produksi pada peternakan yang dimaksud.

\section{Metoda Penelitian}

\subsection{Tahapan Penelitian}

1. Pengumpulan Data

Studi literatur

Studi literatur adalah teknik pengumpulan data dengan cara mereview jurnal-jurnal ilmiah, buku dan berbagai sumber referensi yang terkait tentang penelitian yang akan dibuat, khususnya jurnal-jurnal ilmiah terkait dengan topik yang dibahas. 
2. Metode Pengembangan

Metode yang digunakan pada penelitian ini adalah menggunakan metode SDLC (System Development Life Cycle) dimana metode ini merupakan metode yang sering digunakan oleh penelitian lain. Adapun tahapan dari metode ini adalah :

a. Perencanaan (Planning)

Perencanaan merupakan kegiatan awal dari proses pengembangan perangkat lunak, yang bertujuan untuk menetapkan urutan dalam pengerjaan pengembangan perangkat lunak.

b. Analisa (analyze)

Setelah proses perencanaan dilakukan kegiatan selanjutnya adalah menganalisa kelayakan sistem, mempelajari dan menentukan kebutuhan sistem dimana perangkat lunak akan di operasikan.

c. Perancangan (Design)

Perancangan adalah kegiatan untuk merancang struktur dan keterkaitan antara komponenkomponen sistem sesuai dengan kebutuhan yang sudah ditetapkan, termasuk perancangan interface (antarmuka).

d. Implementasi

Setelah proses perancangan selesai selanjutnya adalah proses implementasi yaitu mengimplementasikan rancangan dari tahap sebelumnya dan melakukan uji coba sistem yang dibuat.

\section{Hasil Penelitian}

\subsection{Analisa Kebutuhan Alat}

Untuk membangun sebuah sistem perhitungan jumlah produksi diperlukan alat untuk menunjang sistem tersebut, adapun alat atau komponen pokok yang harus dimiliki dapat dilihat pada Tabel 1. sebagai berikut :

Tabel 1. Kebutuhan Alat

\begin{tabular}{ll|l}
\hline No & Komponen & \multicolumn{1}{|c}{ Keterangan } \\
\hline & & $\begin{array}{l}\text { Sebuah komputer mini sebesar } \\
\text { kartu kredit yang bertugas } \\
\text { sebagai server dan } \\
\text { penyimpanan history pemakaian } \\
\text { ruangan serta pengontrol } \\
\text { seluruh komponen yang ada }\end{array}$ \\
\hline
\end{tabular}

\begin{tabular}{cl|l}
\hline & & $\begin{array}{l}\text { merupakan papan } \\
\text { mikrokontroler yang berfungsi } \\
\text { memproses input dan output } \\
\text { sistem. Arduino Uno } \\
\text { menggunakan Mikrokontroler } \\
\text { ATmega328 }\end{array}$ \\
\hline 3 & Sensor IR & $\begin{array}{l}\text { Sebuah sensor yang dapat } \\
\text { mendeteksi suatu benda }\end{array}$ \\
\hline 4 & $\begin{array}{l}\text { Sensor } \\
\text { photoresistor }\end{array}$ & $\begin{array}{l}\text { Sebuah sensor yang dapat } \\
\text { mendeteksi jumlah caya }\end{array}$ \\
\hline 5 & Dinamo DC 24 V & $\begin{array}{l}\text { Berfungsi sebagai motor } \\
\text { penggerak. }\end{array}$ \\
\hline 6 & Dinamo servo & $\begin{array}{l}\text { Dinamo servo digunakan } \\
\text { sebagai motor penggerak sekat } \\
\text { pembatas }\end{array}$ \\
\hline 7 & Wire Jumper & $\begin{array}{l}\text { Sebuah kabel khusus yang } \\
\text { menghubungkan seluruh } \\
\text { komponen yang ada ke Port } \\
\text { Port GPIO pada Rapberry Pi }\end{array}$ \\
\hline 8 & Catu Daya & $\begin{array}{l}\text { Sebuah komponen yang } \\
\text { berfungsi untuk memberikan } \\
\text { sumber daya ke komponen yang } \\
\text { ada }\end{array}$ \\
\hline 9 & PIN Header & $\begin{array}{l}\text { Sebuah slot yang berfungsi } \\
\text { untuk menghubungkan } \\
\text { komponen ke papan PCB. }\end{array}$ \\
\hline
\end{tabular}

\subsection{Perancangan Sistem}

Sistem yang dirancang merupakan sistem perhitungan jumlah produksi yang dapat memberikan informasi dengan otomatis serta sistem bersifat client server sehingga dapat diakses dari mana saja dan kapan saja. Berikut merupakan blok diagram sistem perhitungan jumlah produksi yang diajukan.

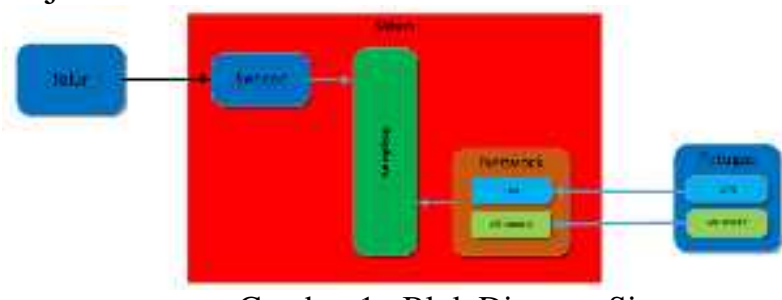

Gambar 1. Blok Diagram Sistem

Dari diagram blok diatas digambarkan bahwa sistem akan melakukan perhitungan jumlah produksi menggunakan sensor, dimana setiap objek yang melalui sensor akan dihitung dengan otomatis. Setiap jumlah perhitungan yang didapat akan disimpan pada sistem yang akan ditampilkan pada web.

Informasi jumlah produksi dapat dilihat menggunakan perangkat komputer, laptop maupun smartphone yang mempunyai koneksi internet baik itu menggunakan LAN maupun WiFi yang dapat menghubungkan perangkat dengan sistem, sehingga 
perhitungan jumlah produksi dapat dilihat dari mana saja dan kapan saja.Berikut merupakan gambaran secara umum perancangan sistem perhitungan jumlah produksi yang diajukan.

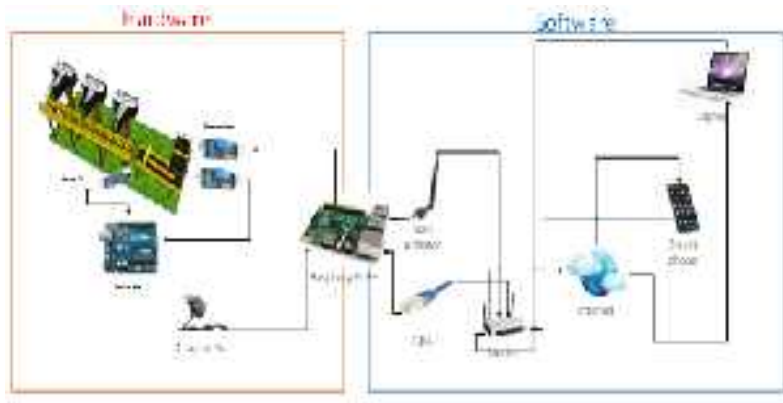

Gambar 2. Perancangan Sistem

Adapun fungsi dari setiap komponen pada perancangan sistem perhitungan jumlah produksi diatas adalah sebagai berikut :

1. Raspberry Pi

Merupakan komputer mini yang berfungsi sebagai modul master yang bertugas untuk mengontrol setiap komponen yang terhubung.

2. Arduino

Merupakan papan mikrokontroler yang berfungsi memproses input dan output sistem. Arduino Uno menggunakan mikrokontrolerATmega328.

3. Sensor IR

Sebuah sensor yang dapat mendeteksi suatu objek yang melewatinya, yang berfungsi mendeteksi ukuran telur

4. Sensor photoresistor

Sebuah sensor yang dapat mendeteksi jumlah caya, yang berfungsi mendeteksi kualitas telur

5. Dinamo DC $24 \mathrm{~V}$

Dinamo DC $24 \mathrm{~V}$ digunakan sebagai motor penggerak jalur lintasan objek

6. Adapter

Adapter memberikan sumber daya listrik pada modul master

7. WiFi-Adapter

Berfungsi untuk menghubungkan modul master kejaringan lokal maupun internet melalui modem.

8. LAN Kabel

Sama halnya dengan WiFi adapter, LAN kabel berfungsi untuk menghubungkan modul master kejaringan lokal maupun internet melalui modem.
9. Modem

Sebagai media penghubung antara modul master ke jaringan lokal maupun internet agar dapat dikontrol dari setiap perangkat yang terhubung kejaringan lokal maupun jaringan internet.

\section{Smartphone/Laptop}

Sebagai perangkat yang akan mengontrol penggunaan listrik ruangan dengan syarat harus berada pada satu jaringan dengan modul master atau pun harus terhubung ke jaringan internet.

\subsection{Perancangan Hardware}

Perancangan hardwaremeliputi perancangan rangkaian komponen-komponen yang dibutuhkan, sehingga tergambar dengan jelas alur dan fungsi-fungsi dari setiap komponen (Rangkaian Sensor IR , Sensor Photoresistor Dan Servo, Rangkaian Arduino dan Dinamo DC, Raspberry Pi, Sensor IR dan Buzzer) serta mengambarkan hubungan antar setiap komponen dengan modul master Raspberry Pi.

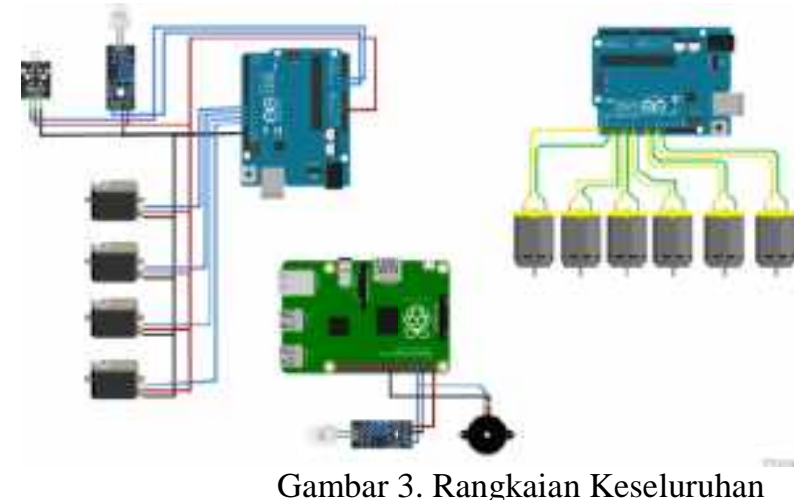

\subsection{Perancangan Jalur Objek}

Untuk dapat dilakukan perhitungan otomatis diperlukan jalur lintasan yang akan menggerakan objek untuk dapat dilakukan perhitungan. Tidak hanya jalur lintasan yang diperlulan tetapi juga diperlukan sekat yang berfungsi untuk mengontrol pergerakan objek yang akan melalui jalur lintasan agar tidak terjadi penumpukan pada jalur lintasan. 


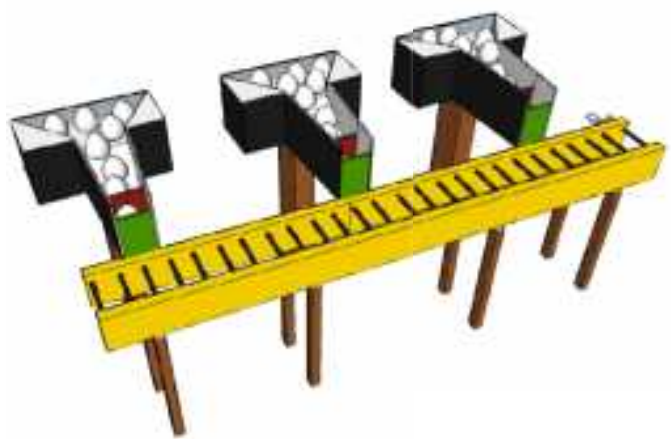

Gambar 4. Desain Jalur Lintasan Ojek dan Sekat Pembatas

Jalur lintasan dirancang sedemikian rupa agar objek dapat begerak dengan lancar tanpa ada kendala sehingga sensor dapat mendeteksi dengan baik dan dapat mengirimkan data ke sistem dengan benar untuk dapat dilakukan perhitungan.

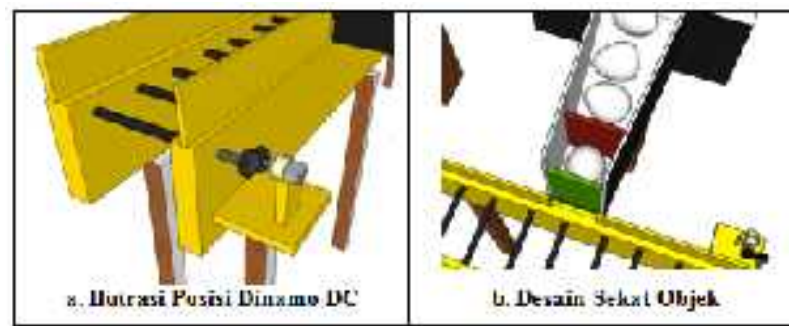

Ciamhar f. Tesain Pratntype Ialur Ohjek dan Sekst Ohyek

Dinamo DC akan menggerakan jalur yang telah dirangkai sedemikian rupa dan perancangan sekat pada objek bertujuan untuk tidak terjadi penumpukan pada jalur lintasan objek.

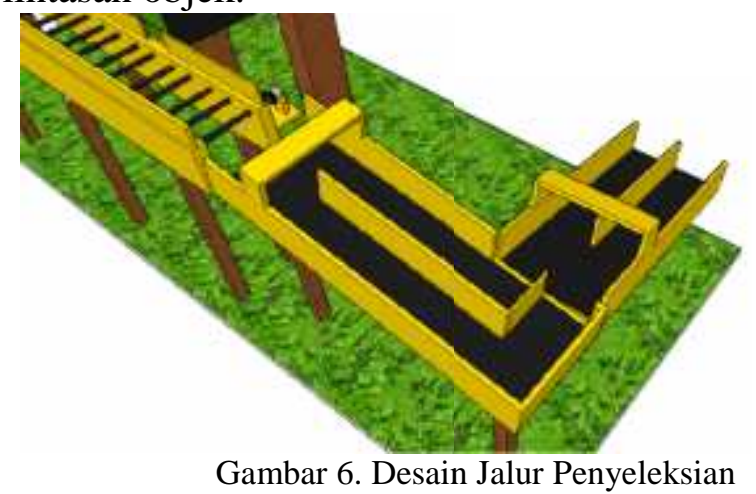

Telur yang telah tedeteksi oleh sensor, akan melalui jalur penyeleksian. Jalur untuk telur yang lulus penyeleksian dan jalur kanan sebaliknya.

\subsection{Perancangan Perangkat Lunak} 3.5.1 Pemodelan Usecase

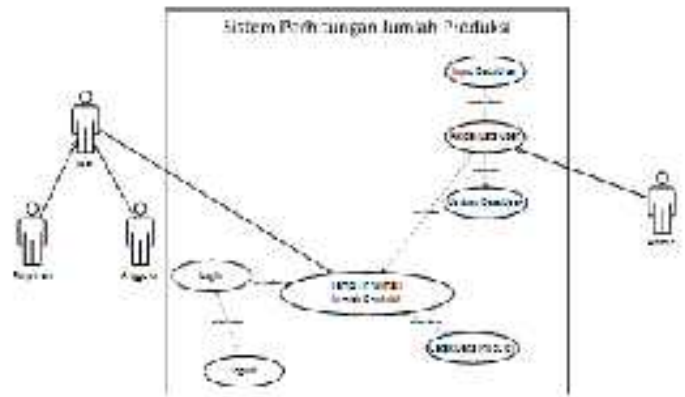

Gambar7. Use case Diagram

\subsubsection{Activity Diagram}

Berikut Activity Diagram setiap pengguna yang terlibat di sistem melalui gambar dibawah ini:

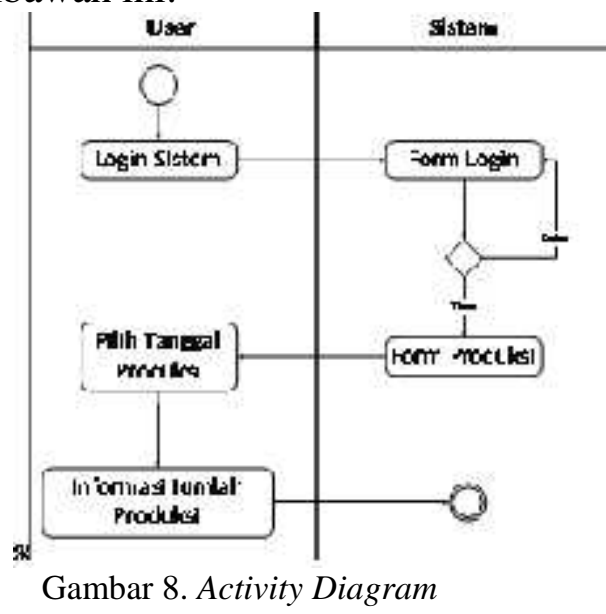

\subsubsection{Class Diagram}
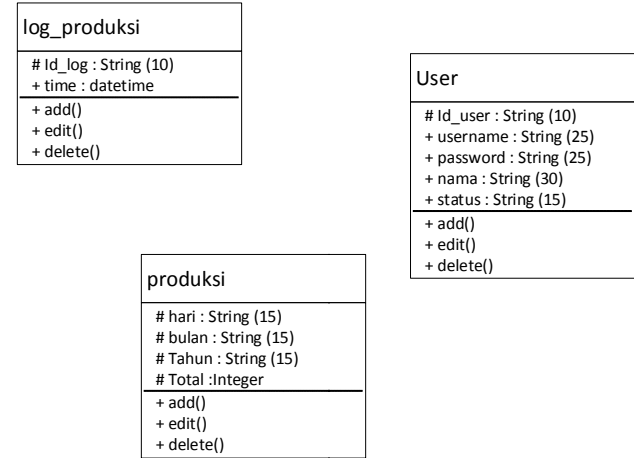

Gambar 9. Class Diagram 


\subsubsection{Sequence Diagram}

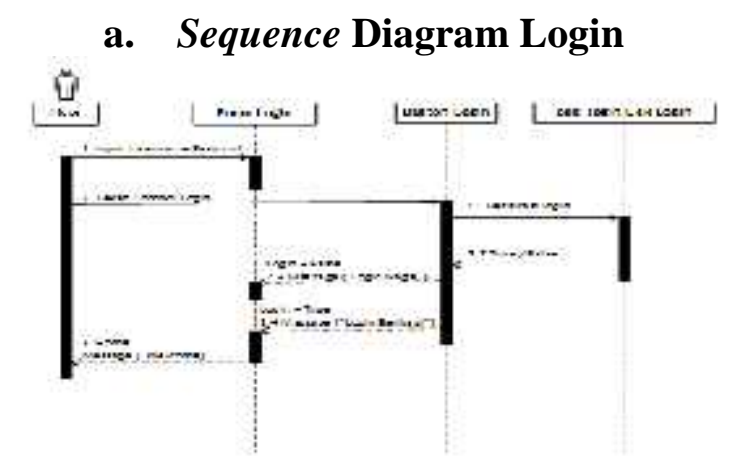

Gambar 10.SequenceDiagram Login

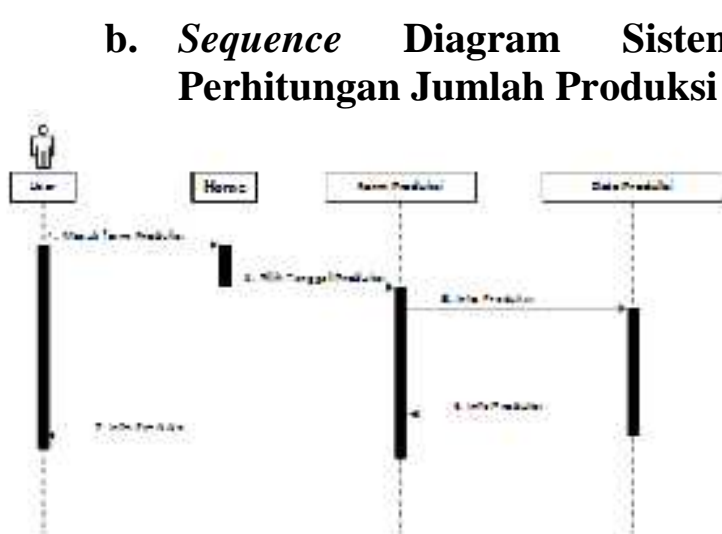

Gambar 11. Sequence Diagram Produksi

\subsection{Desain Form Perhitungan Jumlah Produksi}

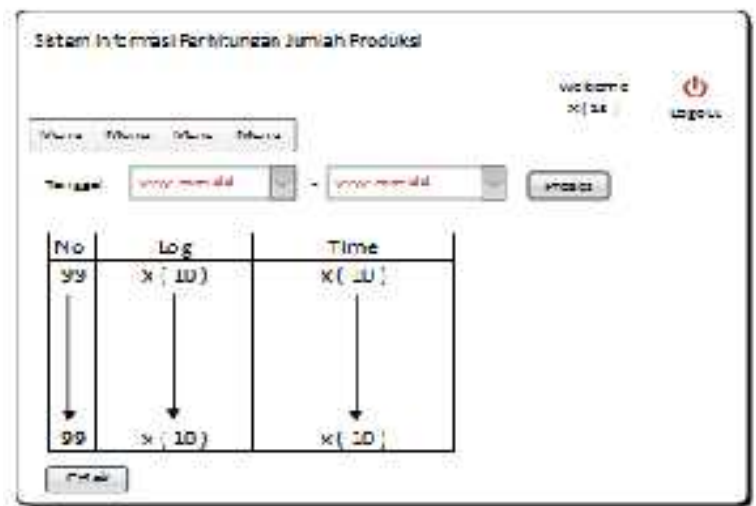

Gambar 12. Desain Form Produksi

Untuk melihat jumlah produksi user harus memilih tanggal yang diinginkan terlebih dahulu, setelah tanggal telah ditetapkan maka user dapat menampilkan data produksi dengan memilih menu proses yang ada. Setelah infomasi jumlah produksi telah ditampilkan maka user dapat mencetak data tersebut.

\subsection{Implementasi}

Pada bagian ini akan ditampilkan implementasi dari sistem yang telah dirancang sebelumnya.

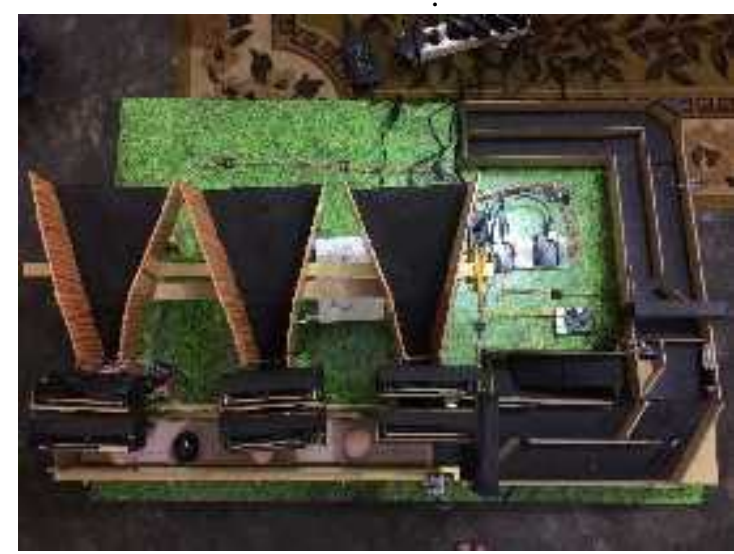

Gambar 13. Tampilan Perangkat Keseluruhan

Perangkat penghitungan telur otomatis secara keseluruhan dapat dilihat pada gambar di atas, pada gambar diatas terdapat 2 bagian utama, yaitu penampungan telur yang dapat mengeluarkan telur otomatis dan jalur penyeleksian telur otomatis.

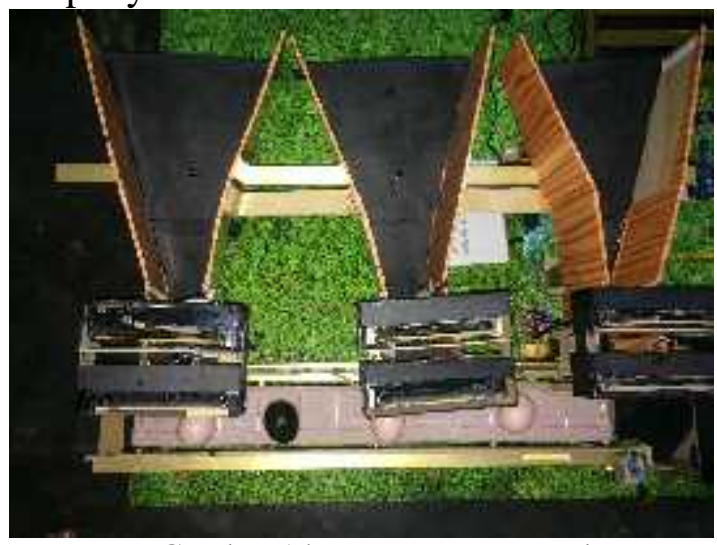

Gambar 14. Penampungan Telur

Penampungan telur befungsi untuk menampung telur yang akan dikeluarkan secara otomatis satu persatu dan akan melalui jalur rel menuju jalur penyeleksian.

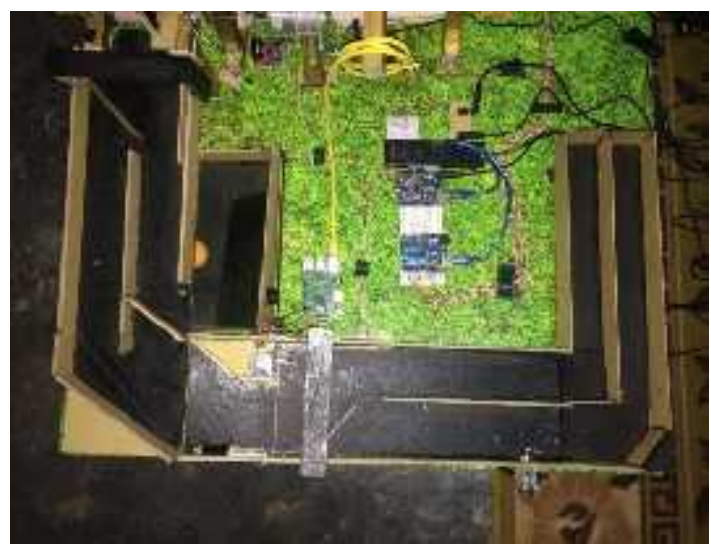

Gambar 15. Jalur Penyeleksian Telur 
Jalur penyeleksian telur terbagi 2 bagian yaitu jalur penyeleksian ukuran telur dan jalur penyeleksian kualitas telur.

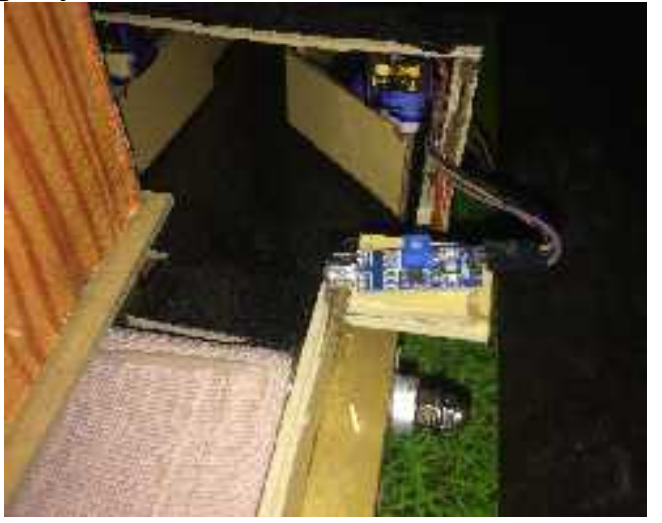

Gambar 16. Sensor Pendeteksi Ukuran Telur

Sensor Pendeteksi ukuran telur bertugas untuk mendeteksi ukuran telur yang akan diteruskan kejalur penyeleksian kualitas telur.

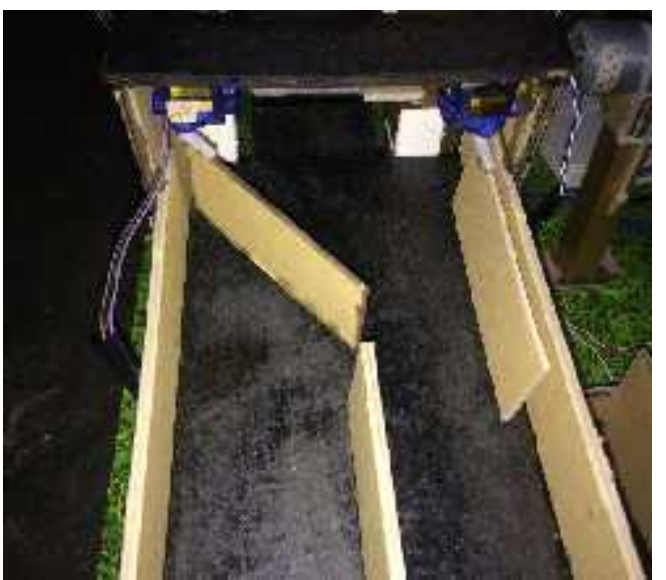

Gambar 17. Palang Penyeleksi Ukuran Telur

Palang penyeleksian telur befungsi untuk memisahkan telur yang telah dideteksi oleh sensor pendeteksi ukuran telur sebelumnya.

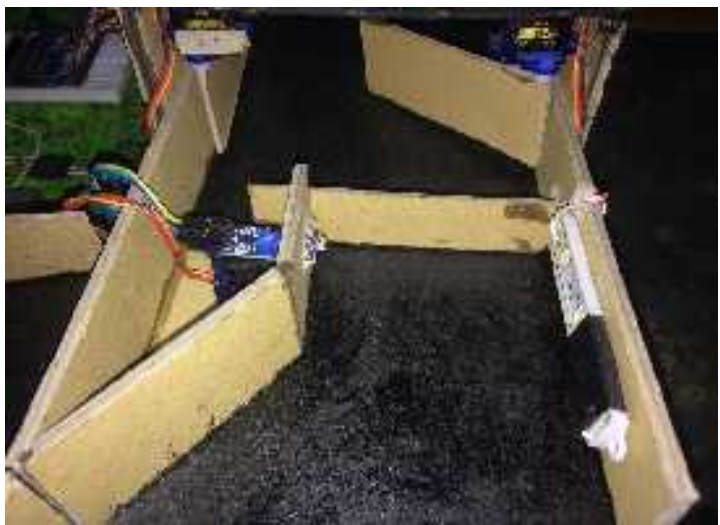

Gambar 18. Sensor Pendeteksian Kualitas Telur

Sensor pendeteksian kualitas telur berfungsi untuk mendeteksi kualitas telur berdasarkan hasil cahaya yang dibiaskan oleh telur. Yang mana telur akan disinari oleh lampu dan akan dideteksi oleh sensor pendeteksi kualitas telur.

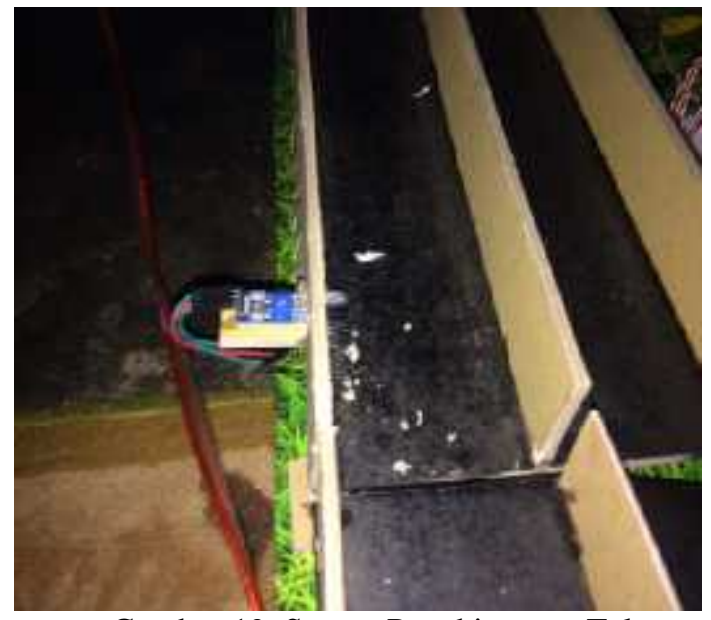

Gambar 19. Sensor Penghitungan Telur

Sensor pehitungan telur berfungsi untuk mendeteksi dan telur yang telah lolos seleksi dari sensor pendeteksi ukuran telur dan sensor pendeteksi kualitas telur.

\subsection{Pengujian Hardware}

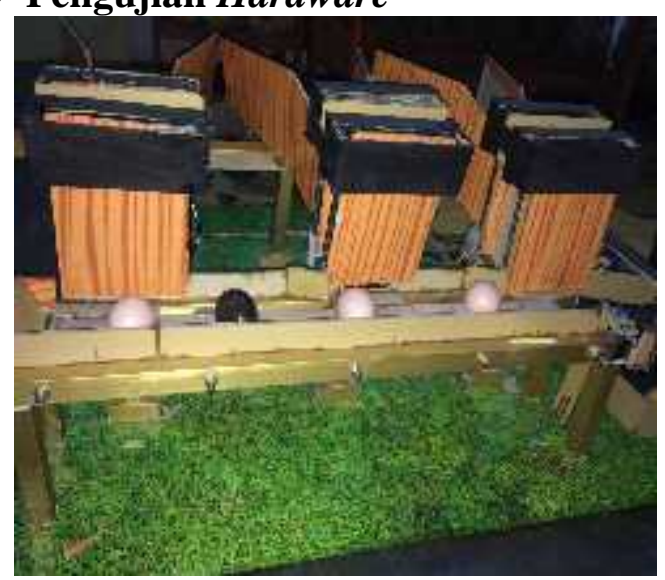

Gambar 20. Telur Melalui Jalur Otomatis

Telur yang keluar dari penampungan akan langsung bergerak menuju jalur penyeleksian menggunakan rel yang telah disediakan. 


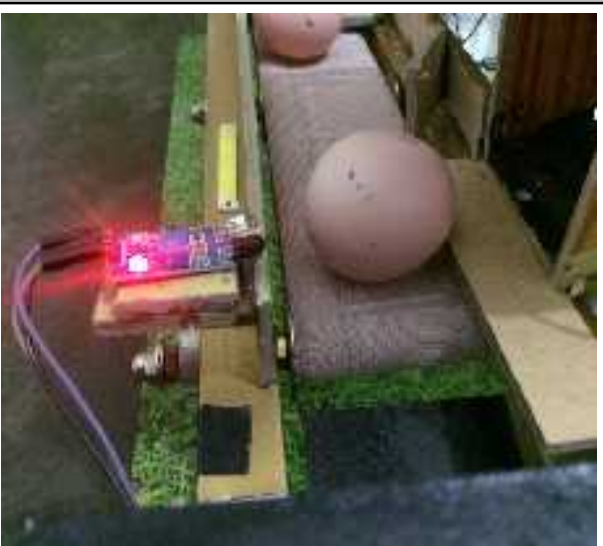

Gambar 21. Telur Melewati Sensor Pendeteksi Ukuran Telur

Telur akan melewati sensor pendeteksi ukuran telur yang kemudian akan bergerak ke sensor pendeteksi kualitas telur.

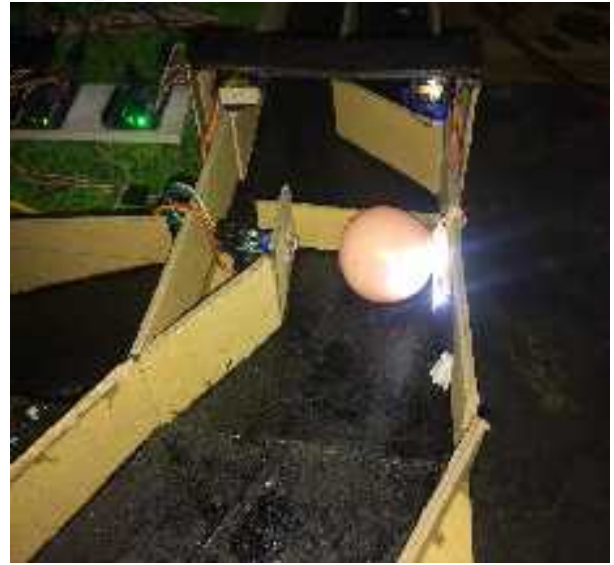

Gambar 22. Telur Melewati Sensor Pendeteksi Kualitas

Setelah didapatkan telur yang memiliki ukuran telur yang standar maka telur akan menuju sensor pendeteksi kualitas telur.

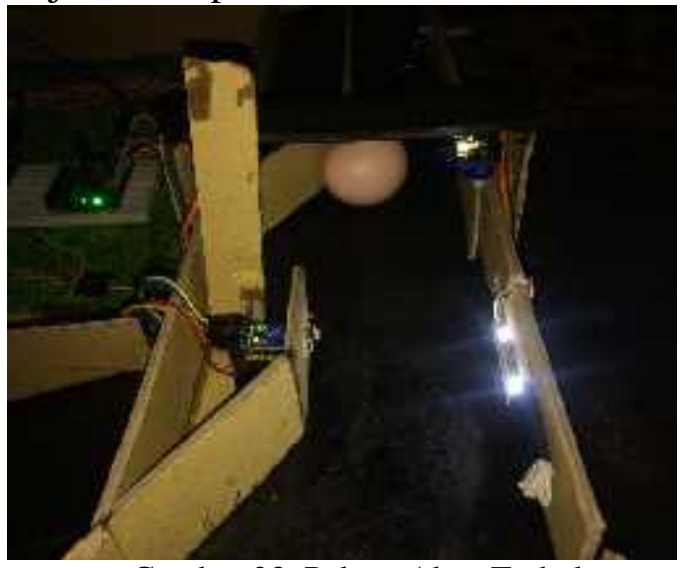

Gambar 23. Palang Akan Terbuka

Pintu palang akan menahan telur selama 3 detik untuk dilakukan pendeteksian kualitas telur berdasarkan bias cahaya yang dihasilkan telur setelah di sinari cahaya.

Telur yang tedeteksi memiliki kualitas yang bagus dan memalui jalur kanan akan melalui sensor perhitungan telur.

\subsection{Pengujian Software}

Sistem pemantauan yang dihasilkan bersifat client-server dimana sistem pemantauan dapat diakses melalui web, sehinga pemantauan dapat dilakukan oleh semua device yang terhubung dengan jaringan modul master.

Berikut merupakan tampilan web sistem pemantauan secara keseluruhan :

\section{a. FormLogin}

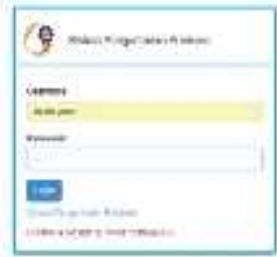

Gambar 24. Form Login

Untuk mengakses sistem pemantauan melalui web, user diharuskan melakukan login terlebih dahulu.Jika login yang dilakukan user diterima oleh sistem barulah user dapat melakukan pemantauan hasil produksi.

\section{b. Halaman Home}

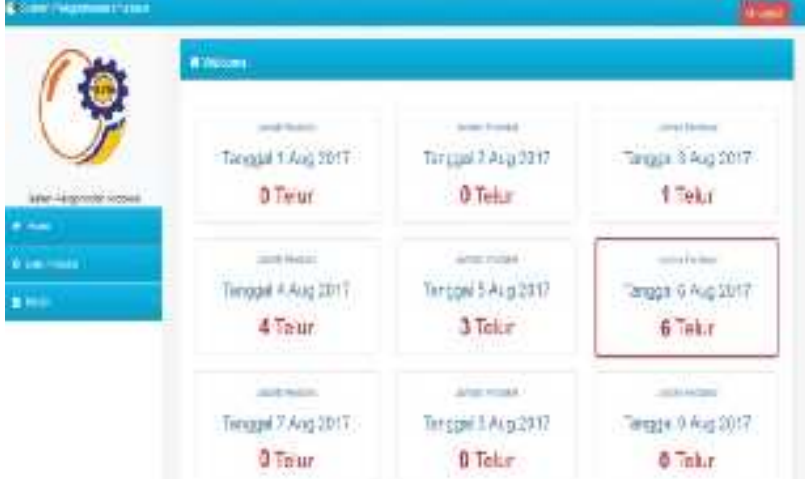

Gambar 25. Halaman Home

Jika berhasil login,user akan masuk pada halaman Home yang memberikan infomasi jumlah produksi setiap hari dalam satu bulan. 
c. Halaman RincianProduksi Harian

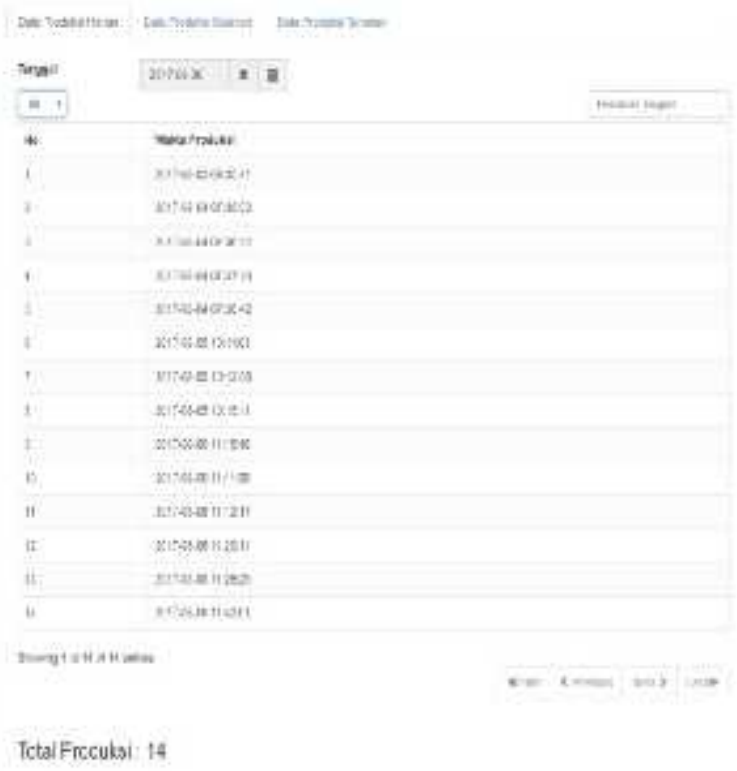

Gambar 26. Halaman RincianProduksi Harian

\section{Kesimpulan}

Beberapa hal yang dapat disimpulkan dari rangkaian kegiatan penelitian, yaknitelah dibuatnya suatu perangkat penghitungan dan pemantauan jumlah produksi ayam petelur menggunakan sensor ultrasonik,sensorinframerah serta sensor pendeteksi cahaya untuk deteksi pergerakan dan konrol seleksi telur.Berdasarkan pengujian yang dilakukan sistem dapat bekerja dengan baik, baik itu dari mekanisme penampungan telur dengan pintu otomatis dan sekat otomatis hingga dalam pendeteksian telur dan dapat hasil produksi dapat dipantau secara langsung melalui laman web.Sistem ini dapat menjadi solusi alternatif dalam sistem pengontrolan dan pemantauan produksi usaha ayam petelur.

\section{Saran}

Untuk penelitian selanjutnya diharapkan pengembangan database dan tampilan program pada laman web dan perangkat tersebut dapat dimanfaatkan untuk jenis produksi telur ternak lainnya seperti telur puyuh, itik dan lainnya.

\section{Daftar Pustaka}

[1] C.C.L. Salele, B. Roimpadey, M. T, Massie, dan P. O. V. Waleleng, "Analisis Penggunaan Faktor Produksi Pada Perusahaan Ayam Ras Petelur (Studi Kasus Pada UD. Kakaskasen Indah san CV. Nawanua Farm)," Jurnal Zootek, vol. 34, Mei 2014, pp.1-14, 2014.

[2] P. Setiabudi, "Prospek Usaha Ayam Petelur di Indonesia," Poultry Indonesia, vol IV, Maret 2009, 2009.

[3] W. K. Sejati, "Analisis Kelembagaan Rantai Pasok Telur Ayam Ras Peternakan Rakyat di Jawa Barat," Jurnal Analisis Kebijakan Pertanian, vol. 9, no 2, Juni 2011, pp.183198, 2011.

[4] Direktorat Jenderal Peternakan dan Kesehatan Hewan Kementerian Pertanian RI, Statistik Peternakan dan Kesehatan Hewan 2015. Jakarta: Direktorat Jenderal Peternakan dan Kesehatan Hewan Kementerian Pertanian RI, 2015.

[5] C. Yohannes, "Sistem Penghitung Jumlah Barang Otomatis dengan Sensor Ultrasonik," Jurnal Ilmiah "Elektrikal Enjiniring" UNHAS, vol.09, no.02, MeiAgustus 2011, pp.66-71, 2011.

[6] A. Ridhamuttaqin, A. Trisanto, Agus dan E. Nasrullah, "Rancang Bangun Model Sistem Pemberi Pakan Ayam Otomatis Berbasis Fuzzy Logic Control," Jurnal Rekayasa dan Teknologi Elektro-ELECTRICIAN, vol.7, no.3, September 2013, pp.125-137, 2013.

[7] S. Suriansyah, S. Muhammad, T. W. F. , Pontia, "Perancangan Sistem Data Logger Dilengkapi MMC Sebagai Pencacah Butir Telur Ayam Berbasis Microcontroller ATMEGA328P," Jurnal Teknik Elektro Universitas Tanjungpura, vol 2, no.1, 2015.

[8] V. Wijayanti, A. Nugroho, "Alat Pendeteksi Telur Berbasis Mikrokontroler PIC16F84," Jurnal ilmiah GO INFOTECH, vol. 21, no.1, Juni 2015, pp.25-30, 2015. 